\title{
Atopy does not predispose to RSV bronchiolitis or postbronchiolitic wheezing
}

\author{
D G SIMS， P S GARDNER，D WEIGHTMAN， M W TURNER，J F SOOTHILL
}

\begin{abstract}
Twenty-six 8-year-old children who had had respiratory syncytial virus (RSV) bronchiolitis in infancy and their paired controls underwent skin and blood tests to assess the role of immunodeficiency and atopy in the pathogenesis of RSV bronchiolitis and the wheezing that may follow it. There was no difference between patients and controls in prevalence of atopy; positive results of prick tests to common antigens; eosinophil counts; yeast opsonisation defect; C2 deficiency; IgG, IgA, IgM, and IgE concentrations; or IgE antibody to dermatophagoides, timothy-grass pollen, and cat fur. Those of the children who had had RSV bronchiolitis and who continued to wheeze had a slightly higher mean eosinophil count and levels of IgE antibody to dermatophagoides than those who did not wheeze. Exercise-induced bronchial lability, though higher in patients than controls, did not correlate significantly with eosinophil counts or IgE concentrations.

The genetic factors predisposing to RSV bronchiolitis and postbronchiolitic wheezing may differ from those predisposing to atopic asthma, though exclusive breast feeding may protect against both.
\end{abstract}

\section{Introduction}

Infants who recover from bronchiolitis caused by respiratory syncytial virus (RSV) often wheeze for some years afterwards. This was confirmed in a controlled study of exercise-induced bronchial lability in such children at the age of $8 .{ }^{1}$ Viral infection, especially RSV, may provoke asthma attacks in asthmatic children $^{2}$; this has led to speculation that RSV and other virus infections may predispose to asthma.

RSV is an endemic infection, and most children develop antibodies to it by the age of 2 years, but only some have bronchiolitis. Though breast feeding ${ }^{3}$ and other environmental factors may contribute to this difference of effect, it is possible that intrinsic factors may do so too. These intrinsic factors may include the common minor immunodeficiencies that underlie much predisposition to respiratory infection, such as immunoglobulin deficiency, ${ }^{4}$ which may be transient, and defective yeast opsonisation. ${ }^{6}$ Atopy is also associated with these immunodeficiencies and with low concentrations of $\mathrm{C} 2,^{78}$ and most childhood asthmatics are atopic.' If bronchiolitis were associated with immunodeficiency, any link between immunodeficiency and subsequent wheezing might be a non-causative association,

Departments of Child Health, Virology, and Medical Statistics, University of Newcastle upon Tyne, Newcastle upon Tyne NE1 7RU

D G SIMS, MRCP, DOSTRCOG, senior research associate (present address: St Mary's Hospital, Manchester)

P S GARDNER, MD, consultant microbiologist (present address: Division of Microbiological Reagents and Quality Control Centre, Public Health Laboratory, London NW9 5DX)

D WEIGHTMAN, statistician

Department of Immunology, Institute of Child Health, London WC1 1EH

M W TURNER, PHD, MRCPATH, reader

J F SOOTHILL, FRCP, FRCPATH, professor or possibly the atopy might have caused excess bronchial lability and so bronchiolitis with RSV infection. Alternatively, since only some infants wheeze after bronchiolitis, they may be the atopic ones.

We therefore recontacted these 8-year-old children who had taken part in the earlier study and their paired controls to assess the role of immunodeficiency and atopy in the pathogenesis of bronchiolitis and of postbronchiolitic wheezing.

\section{Methods}

The parents of the children in the previous study ${ }^{1}$ were contacted by letter seeking permission for their child to have skin and blood tests performed, after obtaining approval from the ethical committee. The parents of 32 children who had had bronchiolitis and of 26 controls consented. Twenty-six pairs of children matched by sex and as closely as possible by age and social class were studied. A history of atopic disease (asthma, eczema, or rhinitis) was taken for the firstdegree relatives of each child and of eczema and rhinitis for the children. All children, except one whose parents allowed blood sampling only, had prick skin tests to timothy grass, Dermatophagoides pteronyssinus, house-dust extract, grass pollen, tree pollen, feathers, mixed moulds, cat fur, dog hair, horse hair, egg, milk, fish, and a negative control (Bencard). The weal diameter was measured after 15 minutes. Weals with diameter more than $3 \mathrm{~mm}$ greater than the control weal were classified as positive; six children produced a weal to the control solution. The results of tests of bronchial lability on exercise have been published previously in the larger series. ${ }^{1}$ Venous blood was taken, separated within two hours, and stored at $-70^{\circ} \mathrm{C}$ until tested. Tests were for total eosinophil counts, serum immunoglobulins $G, A$, and $M$ (measured by radial immunodiffusion), yeast opsonisation, ${ }^{10} \mathrm{C} 2,{ }^{8}$ total IgE concentrations, ${ }^{11}$ and IgE antibody ${ }^{12}$ to the housedust mite, timothy grass, and cat fur.

Parametric data that were not distributed normally were transformed by logarithms, and the children who had had RSV bronchiolitis were compared with their matched controls by Student's paired $t$ test $(26$ pairs). The prevalence of family allergy in the children who had had bronchiolitis and in their matched controls was compared by McNemar's test. Parametric data from those who continued to wheeze after having RSV bronchiolitis and those who did not were compared by Student's $t$ test. There were no matched controls for two children who wheezed and four who did not wheeze, but these children were included in these analyses, making 18 in the wheezing and 14 in the non-wheezing group. Fisher's exact probabilities test was used to compare the groups for history of allergy, positive results of skin tests, defects of yeast opsonisation, and $\mathrm{C} 2$ concentration. Correlation coefficients were calculated to measure the degree of relation between eosinophil count, IgE, and bronchial lability.

TABLE I-Personal and family history of allergy and results of skin tests in 26 children who had had RSV bronchiolitis and their matched controls

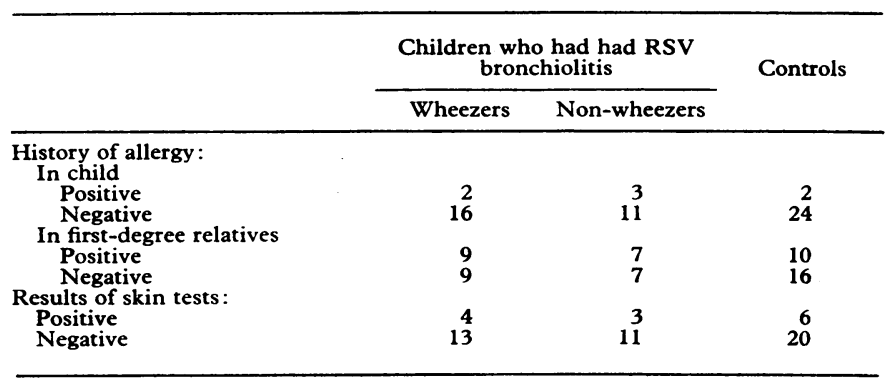


TABLE II-Results of tests on 26 children who had had RSV bronchiolitis (post bronchiolitic group) and their matched controls

\begin{tabular}{|c|c|c|c|c|c|c|c|c|c|c|c|c|c|}
\hline & & & & & \multicolumn{3}{|c|}{ Postbronchiolitic group } & \multicolumn{3}{|c|}{ Controls } & \multirow{2}{*}{$\begin{array}{c}\text { Mean } \\
\text { difference }\end{array}$} & \multirow{2}{*}{$\begin{array}{c}S E \\
\text { of mean }\end{array}$} & \multirow{2}{*}{$\mathbf{p}$} \\
\hline & & & & & $\begin{array}{c}\text { Geometric } \\
\text { mean }\end{array}$ & $\underset{\text { mean }}{\log }$ & SD & $\begin{array}{c}\text { Geometric } \\
\text { mean }\end{array}$ & $\begin{array}{l}\text { Log } \\
\text { mean }\end{array}$ & SD & & & \\
\hline 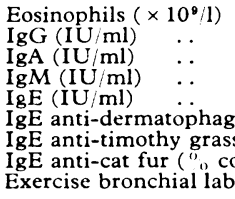 & 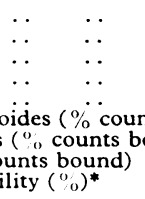 & $\begin{array}{l}\ldots \\
\ldots \\
\ldots \\
\therefore \\
\text { nts } \\
\text { oun } \\
\ldots \\
\therefore\end{array}$ & $\begin{array}{l}\cdots \\
\cdots \\
\cdots \\
\text { nd)* } \\
\cdots \\
\cdots\end{array}$ & $\begin{array}{l}\cdots \\
\cdots \\
\cdots \\
\cdots \\
\cdots \\
\cdots \\
\cdots\end{array}$ & $\begin{array}{c}283 \cdot 8 \\
102 \cdot 8 \\
68 \cdot 5 \\
98 \cdot 7 \\
38 \cdot 8 \\
0.58 \\
0.53 \\
0.55 \dagger \\
21 \cdot 41 \dagger\end{array}$ & $\begin{array}{r}2.453 \\
2.012 \\
1.836 \\
1.994 \\
1.589 \\
-0.238 \\
-0.279\end{array}$ & $\begin{array}{l}0 \cdot 321 \\
0 \cdot 318 \\
0 \cdot 313 \\
0 \cdot 144 \\
0 \cdot 637 \\
0 \cdot 194 \\
0 \cdot 126 \\
0 \cdot 062 \\
12 \cdot 72\end{array}$ & $\begin{array}{c}201.8 \\
105.0 \\
81.8 \\
101.0 \\
35.6 \\
0.54 \\
0.59 \\
0.52 \dagger \\
13.96 \dagger\end{array}$ & $\begin{array}{r}2.305 \\
2.021 \\
1.913 \\
2.004 \\
1.551 \\
-0.268 \\
-0.227\end{array}$ & $\begin{array}{l}0 \cdot 345 \\
0 \cdot 091 \\
0 \cdot 169 \\
0 \cdot 153 \\
0 \cdot 612 \\
0 \cdot 155 \\
0 \cdot 242 \\
0 \cdot 060 \\
8 \cdot 25\end{array}$ & $\begin{array}{l}+0.148 \\
-0.009 \\
-0.077 \\
-0.010 \\
+0.038 \\
+0.030 \\
-0.052 \\
+0.028 \\
+7.45\end{array}$ & $\begin{array}{l}0.085 \\
0.027 \\
0.070 \\
0.035 \\
0.165 \\
0.051 \\
0.053 \\
0.016 \\
3 \cdot 284\end{array}$ & $\begin{array}{l}>0.05 \\
>0.7 \\
>0.2 \\
>0.7 \\
>0.8 \\
>0.5 \\
>0.3 \\
>0.05 \\
<0.05\end{array}$ \\
\hline
\end{tabular}

* Only 25 pairs.

+Arithmetic mean.

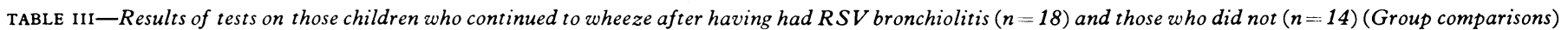

\begin{tabular}{|c|c|c|c|c|c|c|c|c|c|c|c|c|c|c|}
\hline & & & & & & \multicolumn{3}{|c|}{ Wheezers } & \multicolumn{3}{|c|}{ Non-wheezers } & \multirow{2}{*}{$\begin{array}{l}\text { Difference } \\
\text { of mean }\end{array}$} & \multirow{2}{*}{$\begin{array}{l}S E \\
\text { of mean }\end{array}$} & \multirow{2}{*}{$\mathrm{p}$} \\
\hline & & & & & & $\begin{array}{c}\text { Geometric } \\
\text { mean }\end{array}$ & $\underset{\text { mean }}{\log }$ & SD & $\begin{array}{l}\text { Geometric } \\
\text { mean }\end{array}$ & $\underset{\text { mean }}{\log }$ & SD & & & \\
\hline 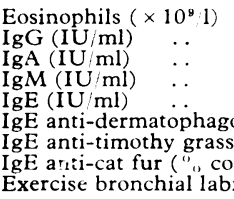 & $\begin{array}{l}\ldots \\
\cdots \\
\cdots \\
\cdots \\
\text { oides (" } \\
(" ., \text { cou } \\
\text { unts bo } \\
\text { ility (". }\end{array}$ & $\begin{array}{l}\cdots \\
\cdots \\
\cdots \\
\cdots \\
\text { (i) coun } \\
\text { unts bo } \\
\text { ound) }\end{array}$ & $\begin{array}{l}\ldots \\
\cdots \\
\cdots \\
\therefore \\
\text { ts bou } \\
\text { ound) } \\
\ldots \\
\ldots\end{array}$ & $\begin{array}{l}\cdots \\
\cdots \\
\cdots \\
\ddot{n d} \\
\cdots \\
\cdots\end{array}$ & $\begin{array}{l}\cdots \\
\cdots \\
\cdots \\
\cdots \\
\cdots \\
\cdots \\
\cdots\end{array}$ & $\begin{array}{c}341 \cdot 8 \\
100 \cdot 9 \\
62.9 \\
93.3 \\
58.7 \\
1.58^{*} \\
0.53^{*} \\
0.57^{+} \\
23.6+^{*}\end{array}$ & $\begin{array}{r}2.534 \\
2.004 \\
1.799 \\
1.970 \\
1.769 \\
0.197 \\
-0.276\end{array}$ & $\begin{array}{c}0.312 \\
0.081 \\
0.345 \\
0.118 \\
0.680 \\
0.682 \\
0.254 \\
0.076 \\
14.8\end{array}$ & $\begin{array}{c}186 \cdot 4 \\
115 \cdot 9 \\
83 \cdot 7 \\
114 \cdot 2 \\
34.9 \\
0.61 \\
0.44 \\
0.55 \dagger \\
16.5 \dagger\end{array}$ & $\begin{array}{r}2.270 \\
2.064 \\
1.923 \\
2.058 \\
1.543 \\
-0.215 \\
-0.357\end{array}$ & $\begin{array}{l}0 \cdot 344 \\
0 \cdot 112 \\
0 \cdot 215 \\
0 \cdot 158 \\
0 \cdot 578 \\
0 \cdot 122 \\
0 \cdot 112 \\
0 \cdot 070 \\
5 \cdot 2\end{array}$ & $\begin{array}{l}+0.264 \\
-0.06 \\
-0.124 \\
-0.088 \\
+0.226 \\
+0.412 \\
+0.081 \\
+0.02 \\
+7.1\end{array}$ & $\begin{array}{l}0 \cdot 116 \\
0.034 \\
0 \cdot 105 \\
0.049 \\
0 \cdot 227 \\
0 \cdot 169 \\
0.069 \\
0.026 \\
3.85\end{array}$ & $\begin{array}{l}<0.05 \\
>0.05 \\
>0.2 \\
>0.05 \\
>0.3 \\
<0.05 \\
>0.2 \\
>0.4 \\
>0.05\end{array}$ \\
\hline
\end{tabular}

*17 children tested.

+ Arithmetic mean.

\section{Results}

The postbronchiolitis group and their controls did not differ significantly in age (mean $8 \cdot 28 \pm 0 \cdot 24$ and $8 \cdot 29 \pm 0 \cdot 25$ years respectively) or social class. There was no statistically significant difference in the family history of wheezing, eczema, and allergic rhinitis or in the personal history of eczema and rhinitis between the postbronchiolitis groups and control groups (table I). As with the previously reported larger series, the children who had had RSV bronchiolitis had on average greater exercise bronchial lability than their controls (table II). There were no significant differences between concentrations of eosinophils, any of the immunoglobulins, or IgE antibodies. IgA was not detected in one child who continued to wheeze after having RSV bronchiolitis. No child gave values of $\mathrm{C} 2$ below the critical value of $50^{\circ}{ }_{0}$ for susceptibility to atopy, ${ }^{8}$ and the proportion with yeast opsonisation below the critical value of $28 \%$ was similar in the two groups (two out of 32 who had had bronchiolitis and three out of 26 controls).

There were no significant differences in prevalence of history of allergy in the children or first-degree relatives, or positive results of prick test in the children who had suffered RSV bronchiolitis who subsequently wheezed and those who did not (table I). The frequency of defective $(<28 \%$ ) yeast opsonisation (one in each group) was also similar. Though the mean value for exercise lability was greater in the group with wheezing, surprisingly this was not significant. The trend for IgG, IgM, and IgA concentrations to be lower in those who wheezed and IgE concentration and IgE antibody to cat fur and timothy pollen to be higher were not significant, but IgE antibody to $D$ pteronyssinus and the eosinophil counts were on average just significantly higher in those who wheezed (table III).

There was no significant correlation between exercise lability, eosinophil count, or IgE concentrations in any of the groups (table IV). IgE and eosinophil counts, however, correlated strongly in all groups except the non-wheezers (table V). This suggested that there was an independent heterogeneity within the population, presumably atopy, which was independent of the effects of RSV.

\section{Discussion}

Yeast opsonisation defect and C2 deficiency are associated with atopy, ${ }^{8}$ but our findings suggest that neither immunodeficiency increases vulnerability to RSV bronchiolitis or to the wheezing that may follow it. Transient IgA deficiency, also associated with atopy, ${ }^{7}$ may increase vulnerability but as it cannot be
TABLE IV-Degree of association of exercise lability with IgE concentration and eosinophil counts (none are statistically significant)

\begin{tabular}{lcccc}
\hline & \multicolumn{3}{c}{ Postbronchiolitics } & Healthy \\
\cline { 2 - 4 } & $\begin{array}{c}\text { All } \\
(\mathrm{n}=31)\end{array}$ & $\begin{array}{c}\text { Wheezers } \\
(\mathrm{n}=17)\end{array}$ & $\begin{array}{c}\text { Non-wheezers } \\
(\mathrm{n}=14)\end{array}$ & $\begin{array}{l}\text { children } \\
(\mathrm{n}=26)\end{array}$ \\
\hline IgE concentration & +0.243 & $\begin{array}{l}+0.281 \\
+0.412\end{array}$ & $\begin{array}{l}-0.003 \\
-0.067\end{array}$ & $\begin{array}{l}-0.056 \\
+0.024\end{array}$ \\
\hline Eosinophil count & +0.350 & & & \\
\hline
\end{tabular}

TABLE V-Degree of association ( $r$ ) and significance $(p)$ of eosinophil counts and IgE concentrations

\begin{tabular}{|c|c|c|c|c|c|c|c|}
\hline \multicolumn{6}{|c|}{ Postbronchiolitics } & \multirow{2}{*}{\multicolumn{2}{|c|}{$\begin{array}{l}\text { Healthy } \\
\text { children } \\
(n=26)\end{array}$}} \\
\hline \multicolumn{2}{|c|}{$\begin{array}{c}\text { All } \\
(n=32)\end{array}$} & \multicolumn{2}{|c|}{$\begin{array}{l}\text { Wheezers } \\
(n=18)\end{array}$} & \multicolumn{2}{|c|}{$\begin{array}{l}\text { Non-wheezers } \\
(n=14)\end{array}$} & & \\
\hline $\mathbf{r}$ & $\mathrm{p}$ & $\mathbf{r}$ & $\mathrm{p}$ & $\mathbf{r}$ & $\mathrm{p}$ & $\mathbf{r}$ & $\mathrm{p}$ \\
\hline+0.577 & $<0.001$ & +0.771 & $<0.001$ & +0.275 & $>0.05$ & +0.723 & $<0.001$ \\
\hline
\end{tabular}

detected retrospectively we could not investigate this. The only significant difference between the children who continued to wheeze after suffering RSV bronchiolitis and those who did not was that those who wheezed had slightly higher eosinophil counts and IgE antibody to dermatophagoides. We confirmed that atopy was not associated with previous RSV infection, nor was it associated with positive results of skin prick tests, family history of atopy, or a range of in-vitro correlates of atopy. Atopy occurred independently in all groups, suggesting that neither atopy nor factors with which it is associated predispose to RSV bronchiolitis. The prevalence of atopy and yeast opsonisation defect in all groups is compatible with previous studies in British children. ${ }^{13} 10$

These findings suggest that persistent postbronchiolitic wheezing differs from other asthma. It has been suggested that primary excessive bronchial lability may predispose to asthma, ${ }^{14}$ but since nearly all asthmatic children are atopic lability may be an effect rather than a cause. Lability or other local variation in the bronchioles may explain the different effects of RSV infection. The slightly higher eosinophil counts and IgE anti- 
dermatophagoides antibody, and the one patient with $\operatorname{IgA}$ deficiency, in those who continued to wheeze, suggest that these factors may also influence the effects of the infection in some patients.

This difference between postbronchiolitic wheezing and asthma could influence treatment. Bronchodilators may be useful for both, but measures such as antigen avoidance and treatment with sodium cromoglycate may be suitable only for atopic asthma.

Exclusive breast feeding protects against both RSV and atopic disease. Although the genetic factors predisposing to RSV bronchiolitis and postbronchiolitic wheezing appear to differ from those predisposing to atopic asthma exclusive breast feeding may protect against both.

We are grateful to Dr M A P S Downham for help and encouragement, Professor J F Mowbray for the C2 determinations, and Mrs S Odjhavi and Miss J Gibson for technical help.

\section{References}

1 Sims DG, Downham MAPS, Gardner PS, Webb JKG, Weightman D. Study of 8-year-old children with a history of respiratory syncytial virus bronchiolitis in infancy. $\mathrm{Br} \mathrm{Med} \mathcal{F} 1978 ; \mathrm{i}: 11-14$.

2 McIntosh K, Ellis EF, Hoffman LS, Lybass TG, Eller JJ, Fulginiti UA. The association of viral and bacterial respiratory infections with exacerbations of wheezing in young asthmatic children. $\mathcal{F}$ Pediatr 1973; $82: 578-90$.

${ }^{3}$ Downham MAPS, Scott R, Sims DG, Webb JKG, Gardner PS. Breast feeding protects against respiratory syncytial virus infections. $\mathrm{Br} \mathrm{Med} \mathcal{f}$ 1976 ;ii:274-6.

4 Donovan R, Soothill JF. Immunological studies in children undergoing tonsillectomy. Clin Exp Immunol 1973;14:347-57.

5 Östergaard PA. IgA levels and carrier rate of Haemophilus influenzae and $\beta$ haemolytic streptococci in children undergoing tonsillectomy. Acta Pathol Microbiol Scand [C] 1976;84:290-8.

6 Soothill JF, Harvey BAM. Defective opsonisation, a common immunity deficiency. Arch Dis Child 1976;51:91-9.

7 Taylor B, Norman AP, Orgel HA, Stokes CR, Turner MW, Soothill JF. Transient IgA deficiency and the pathogenesis of infantile atopy. Lancet 1973;ii:111-3.

8 Turner MW, Mowbray JF, Harvey BAM, Brostoff J, Wells RS, Soothill JF. Defective yeast opsonisation and C2 deficiency in atopic patients. Clin Exp Immunol 1978;34:253-9.

${ }^{9}$ Godfrey S. Problems peculiar to the diagnosis and management of asthma in children. BTTA Rev 1974;4:1-16.

${ }^{10}$ Levinsky RJ, Harvey BAM, Paleja S. A rapid objective method for measuring the yeast opsonisation activity of serum. $\mathcal{F}$ Immunol Methods $1978 ; 24: 251-6$.

11 Nye L, Merrett TG, Landon J, White RJ. A detailed investigation of circulating IgE levels in a normal population. Clin Allergy 1975;1:13-24.

12 Turner MW, Brostoff J, Mowbray JF, Skelton A. The atopic syndrome; in vitro immunological characteristics of clinically defined subgroups of atopic subjects. Clin Allergy 1980;10:575-84

13 Godfrey RC, Griffiths M. The prevalence of immediate positive skin tests to Dermatophagoides pteronyssinus and grass pollen in school children. Clin Allergy 1976;6:79-82.

14 Konig P, Godfrey S. Prevalence of exercise-induced bronchial lability in families of children with asthma. Arch Dis Child 1973;48:513-8.

(Accepted 26 May 1981)
ONE HUNDRED YEARS AGO Miss D, aged 32, consulted me on October 26th, 1877, complaining of severe pain in the back, prolapse of the rectum, costiveness, and great agony during and after defaecation. There was also great irritability of the bladder. The catamenia were regular, and not very excessive. On examining per vaginam, a hard rounded mass, somewhat larger than a cricket-ball, could be felt, firmly attached to the lower and posterior part of the uterus, filling Douglas's space, and pressing upon the rectum. The os uteri appeared normal, but somewhat patulous. The uterine cavity was half an inch above its normal length. The patient was ordered to take bromide of ammonium and chloride of ammonium three times daily, and Indian hemp every evening. After continuing these remedies for about four weeks without any relief to her sufferings, she entreated me to remove the tumour. I explained to her that no cutting operation would be justifiable. This opinion was based on the position of the tumour, and its close connection with the uterus. I then informed her that I had for some time past contemplated, in a suitable case, when medical treatment had failed to give relief, attempting the removal of such a tumour by another method; one, however, that was by no means without very considerable risk. She replied that she did not care what I did to her; that she would rather die than continue as she was, her sufferings being intolerable. I then explained to her, that what I proposed doing was to pass a red-hot iron into the tumour through the vagina, to which proposal she readily consented. I was fully cognisant of the good results following the treatment adopted by Drs Greenhalgh, Routh, Meadows, myself, and probably others, by cauterising intra-uterine or submucous fibroids. I was also well aware that pedicles and other portions of the peritoneum in ovarian operations had been frequently severed by the actual cautery, without any injurious results.

On November 22 nd, the bowels having been thoroughly cleared, chloroform was administered by my son, Mr Trevor Wynn Williams of Brixton. The patient being under its influence, I introduced a largesized speculum; and after ascertaining, by means of the sound used as a probe, the most prominent part of the tumour, I passed a red-hot pointed wire of the thickness of a crow's quill into the tumour; then withdrew it, and passed along the same tract another red-hot wire of the size of a swan's quill. On withdrawing this, about half an ounce of clear transparent yellow fluid followed, which at first sight had much the appearance of urine; but, whilst I was examining the bladder for fear some accident might have occurred, the liquid, cooling immediately, coagulated; which, together with the examination, fully satisfied me that it was the contents of a cyst situated in the centre of the tumour. The speculum was then withdrawn, and a morphia suppository introduced into the rectum.

When I visited her on the following day, little or no constitutional disturbance had manifested itself, and she had passed a very tolerable night. The nurse was ordered to syringe out the vagina three or four times a day with a weak solution of iodine, to prevent any septic poisoning; and to insert another morphia suppository, if required. With the exception of some trouble with the bowels, owing to the prolapse, which was very great, she went on without anything worthy of note occurring until the 29th, seven days after the wires had been introduced; when, on my visiting the patient, the nurse informed me that, after syringing, several large pieces of slough had passed; but, much to my annoyance, she had not preserved them. On making an examination per vaginam for the first time since the cauterising, I found the tumour much reduced in size and softened, and was able to pass my finger into the hole where the cautery had been inserted in the upper part of the vagina, adhesion having taken place all round it. The prolapse of the gut was still so large and painful, that I contemplated removing a portion with the cautery; but in the meantime opiate fomentations were kept constantly applied, and confection of senna taken occasionally, until the morning of December 7 th, when I received a telegram requesting me to visit the patient immediately, as she was taken suddenly worse. On my arrival, I learned that, on the previous evening, my patient had been frightened by hearing her servant fall down stairs; and that, shortly afterwards, haemorrhage had set in, and continued till the bedclothes were perfectly saturated. I was glad to find, however, on examination, that the haemorrhage did not proceed from the wound, but from the uterus itself. The vagina $\mathrm{O}$ was at once plugged with pledgets of cotton-wool saturated with one part of the strong solution of perchloride of iron in two parts of water; $N$ a scruple of gallic acid, dissolved in warm water, was ordered to be $>$ taken every three hours; warm milk, with a little brandy, being 으. administered frequently. After remaining with the patient some time, I was glad to find that the haemorrhage had ceased; and it did not $\mathrm{N}$ recur. I removed the plugs on the second day. I was now, $\omega$ owing to the relaxed state of the parts, able to replace the prolapsed bowel, placing a T-bandage with a firm pledget of wool 0 over the anus. The bowel did not again become prolapsed. From this time, nothing untoward occurred. The wound continued to discharge $\stackrel{\mathscr{D}}{\rightarrow}$ for some time, the vagina being frequently washed out with the $\nabla$ iodine lotion. With generous diet and tonic medicines, she soon $\overline{0}$ regained her strength. Some weeks afterwards, on making an examina- $\overrightarrow{\mathbb{D}}$ tion per vaginam et rectum, I could discover nothing more than a small $\frac{\rho}{\mathbb{D}}$ nodule where the tumour had been attached to the uterus, a little $\varrho$ above the junction of the body with the cervix; and this in course of time became still smaller, and has continued so ever since. In fact, I do 0 not think a stranger would discover even this slight elevation on examination. She is now in the enjoyment, I may safely say, of perfect health, menstruating regularly, requiring only an occasional mild $\frac{\bar{\sigma}}{\partial}$ aperient. British Medical fournal, 1881.) 